\title{
Umbrella-Canopy as an Icon of Braga Permai Restaurant in Bandung
}

\author{
Setiamurti Rahardjo ${ }^{1}$, Andreas D. Handoyo ${ }^{2}$ \\ ${ }^{1,2}$ School of Creative Industries, Telkom University, Bandung, Indonesia \\ icusrahardjo@tcis.telkomuniversity.ac.id (Setiamurti Rahardjo), ashandoyo@tcis.telkomuniversity.ac.id (Andreas D. Handoyo)
}

\begin{abstract}
Braga Permai restaurant is well known as one of heritage buildings in Bandung. Through times, the building has been going through renovations which have changed the general form and facade, preserving the umbrella-canopies at the outdoor seating area as an icon. The intention of keeping this iconic exterior element comes from the restaurant management as the umbrella-canopies have been popular as the building landmark since its renovation in 1923. In addition, the restaurant has also started to use the image of the umbrella-canopy on the menu books and website. Nevertheless, do people today still perceive the image of those canopies as iconic as they were in the previous time? Through quantitative approach accompanied by questionnaires, this paper aims to find what people perceive as an icon of Braga Permai today and how representative the umbrella-canopy is as an icon. As the result, it is found that umbrella-canopy is perceived as an icon not merely by architectural design, but also by a supporting contribution of visual graphic.
\end{abstract}

Keywords braga permai restaurant, umbrella-canopy, icon, architecture elements.

\section{Introduction}

Conservation of heritage buildings in Bandung seems to be a perpetual topic among architects, urban planners, and the government. Regardless the endeavor to keep the building facades and appearances be as they were in the past, renovation can sometimes be unavoidable due to many reasons, such as climate adjustment [1], economic development [2], tourism influence [3], or urban morphology and planning $[4,5]$. Located at the heart of Bandung's heritage area, Braga Permai Restaurant has been going through several changes, which involve renovations to its building and facade $[2,6]$.

Formerly named Maison Bogerijen [6], the restaurant was built in 1918 with a garden sheltered by trees. Later in 1923, the restaurant was moved to the present location at Braga Street, enforcing the restaurant to change its building appearance. Losing the trees in the outdoor area, this restaurant then used umbrella-canopies to shade the outdoor dining. Since that period of time, this restaurant has experienced many stages of business, starting from its glory in the early 1920s, changing name to Braga Permai, renovations, busi- ness downfall (specific timeline unrecorded), the recent revival in the 2010s, until it is listed now on no. 6 out of 1560 restaurants in Bandung [7].

Along the situations and changes, now Braga Permai still use umbrella-canopies in the outdoor area. Even though the present building and its exterior appearance have been completely transformed, the umbrella-canopies are still placed in the same area as they were designed in 1923 (e.g. Figure 1 and Figure 2). The noticeable difference is that the restaurant now shows only three umbrella-canopies on the terrace, contrast to how many were used in the past time. Based on photo observation, this happens since the renovated building already has a wide overhang to cover some parts of the terrace, thus only fewer umbrella-canopies are needed to shade the rest of the outdoor seating area. 


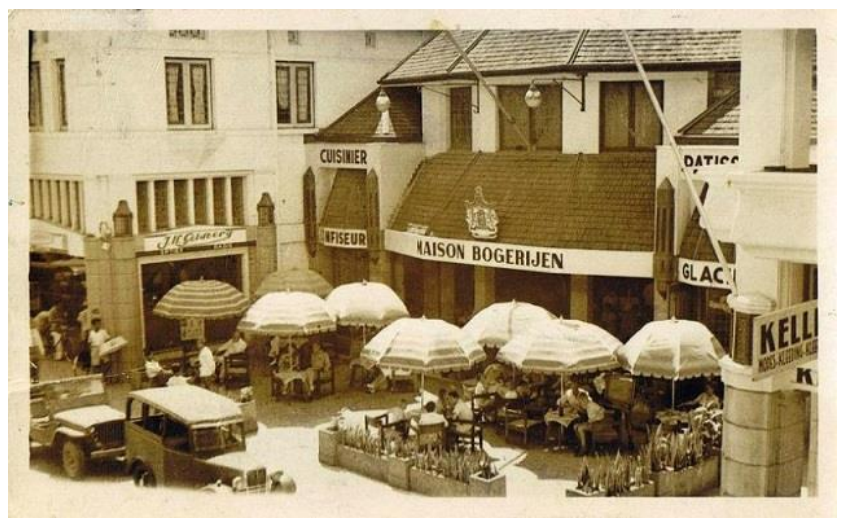

Figure 1. Maison Bogerijen, 1923

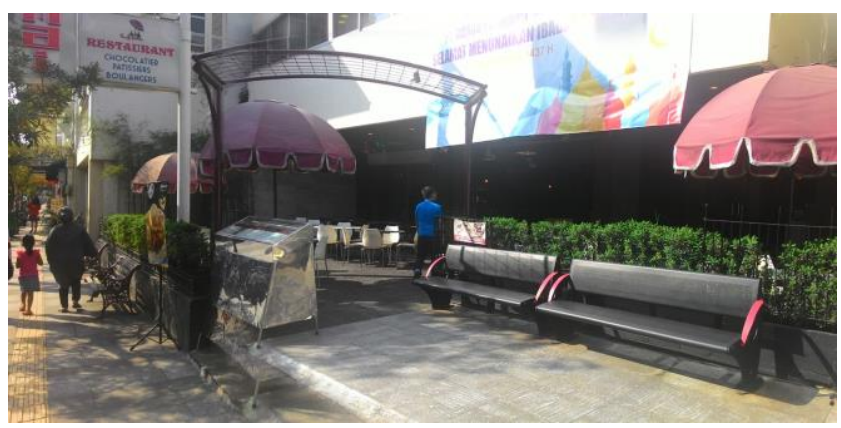

Figure 2. Braga Permai Restaurant, 2016

The intention to keep the image of the umbrella-canopies comes from the restaurant management as a means to preserve the memory of the past. Despite of the reason why umbrella canopies are chosen, those are seen to be the only outdoor elements remaining from the past design. Even though they slightly change the material, pattern, and form while the canopies are damaged or broken by age, but the existence are maintained to be in the same location with similar design. The restaurant also makes such an effort to preserve this element by using the same image as a logo on their menu books and websites.

However, the intention of the restaurant does not instantly come to an end in the eyes of the guests or restaurant visitors merely by choosing one of the restaurant elements as a preserved sign. This image perhaps was iconic for Maison Bogerijen as it was a very famous cafe-restaurant back then, where the traders around the area could rest at the restaurant after doing their business along Braga Weg and Groote Postweg, and the Preangerplanters in the uphill used to travel down by the weekend to dine in at this restaurant [6]. Meanwhile, using umbrella-canopies for outdoor restaurants was very popular and supposedly was influenced by the Empire Style brought by Daendels in the era of Dutch colo- nization [1]. Placing them in the outdoor setting of Maison Bogerijen surely made the traders able to spot the location and the image could easily be a landmark of the area, especially when pointing to a restaurant. Nevertheless, not every people today knows the history of Braga Permai and thus they way they see the image of the umbrella-canopies might be different from people in the past time or people who understand the former stories of this restaurant.

This paper aims to find what people perceive as an icon of Braga Permai today and whether the image of an umbrella-canopy is representative as an icon of this restaurant. The findings are later to be used as an information for the restaurant to develop their business through architectural and visual design and accordingly support the sustainability of the cultural heritage in Bandung as well.

\section{Literature Review}

\subsection{Icon as a Sign}

Icon is known as a part of sign as described in the modern semiotic theory proposed by Charles Sanders Peirce (1839-1914) [8] (p. 102), [9]. The theory of sign is also introduced by Ferdinand de Saussure (1857-1913), which explains that a sign is expressed through language codes resulted from an imagination or an activity in human minds with a purpose and specific meaning intentionally $[9,10]$, whereas Peirce emphasizes that a sign only requires the ability to represent something according to the individual's interpretation and thought [9]. Rooted from Peirce's understanding of sign, icon is described as a sign which has relations to its object through similarity [11] (p.16), [8] (p. 100). The similarity itself is formed in one's sense when perceivers already have some persisting knowledge or expectation to assess that an image is similar to something and thus viewed as an icon [12]. This means that icon is closely related to one's perception that can create a visual image.

\subsection{Perceiving Icon through Visual Experiences}

A process of perceiving a certain object as an icon requires background experiences [12]. Peirce describes that those experiences assembled in one's mind as a "composite photograph" [13]. Although perception usually requires spatial experience which can be created through sound and visual aspects $[14,15,16]$, referring to the word "photograph" used 
by Peirce, the process emphasizes on visual experience. This statement is in line with what is mentioned by Kimchi, et.al, [17] that "perceptual organization and visual attention are crucial for the perception of our visual environment". Related to the Gestalt theory about how people interpret their surrounding space visually, people are able to easily associate order that has minimum irregular or complex form [18]. This means a constant or consistent pattern or composition of visual elements are important to create a positive visual experience. In the field of design, those elements can be found in shape, color, size, and other common design elements [11] (p. 47-51).

\section{Methods}

The paper is performed through quantitative approach with using questionnaires as the main tool. The questionnaires are spread through social media between June 1-6, 2017 to people in Bandung who have visited Braga Permai without differentiating age, genders, or social groups. The questionnaires show photographs of several features in the restaurant to stimulate visitors' memories about remarkable design elements in Braga Permai which can be iconic according to their perceptions. Due to the rare use of the second floor, the photographs only show images of the first floor indoor and outdoor dining area. The VIP dining room is also excluded since the access to the area requires a reservation and it is not visible by every visitor. The questionnaires are also used to give information whether or not the visitors agree about the image of umbrella-canopy is iconic for the restaurant. An interview with the most senior waiter, who has been working, for more than 30 years. An interview is also performed to gather an overall information about business stages and the brief history of Braga Permai.

\section{Findings and discussion}

After the respondents make three selections by choosing three out of eight elements (furniture, ornament or decoration, atmosphere, colors and materials, architecture, Braga Street, and food and drinks) which respectively memorable for them regarding the restaurant, 66 valid responses are acquired and described as:

- first three memorable elements: Braga Street (33\%), atmosphere (30.5\%), food and drinks (23.5\%)
- $\quad$ second three memorable elements: atmosphere (32\%), Braga Street (25\%), food and drinks (23.5\%)

- $\quad$ third three memorable elements: food and drinks (23.5\%), architecture (20\%), atmosphere (20\%)

Braga Street, atmosphere, food and drinks, and architecture are selected the most memorable elements according to the respondents. In the average of the total three selections, the responses of every category are shown in the list below:

- atmosphere $(27.5 \%)$

- Braga Street $(23 \%)$

- food and drinks $(20.67 \%)$

- architecture $(13.17 \%)$

- ornament or decoration $(8.50 \%)$

- furniture $(5.17 \%)$

- colors and materials $(1.50 \%)$

- others $(0.50 \%)$

It is seen from the result that atmosphere is crucial in creating a memorable experience, as it is always mentioned in every selection and proven to be on the top list of the average result. The interesting finding is that although food and drinks is always mentioned on the selection, but it was listed after Braga Street which comes in two out of the three selections. This means that how frequent the category is selected does not determine its importance in creating a memorable experience.

The percentage of the average also tells that categories which represent smaller scale objects are less selected. When the category becomes more detail, it tends to be less selected. In the opposite, it means that people generally perceive memories of a place through what they view in a large scale without a further effort to pay attention to more detail parts of the place. Even though atmosphere gets the highest percentage, Braga Street is considered to have the biggest role in creating visual memory, since atmosphere contains of many non-visual elements that can be intangible.

Looking further on the design elements, the second part of the questionnaires asks the respondents to mention specific parts of the building which are remarkable for them. Aided by photographs to help them recall their memories, the result is shown in this order:

- $\quad$ Signage typography of Braga Permai (23\%)

- Umbrella-canopy (18.6\%)

- Gate and exterior space (15.9\%)

- Tables near pastry display $(11.5 \%)$ 
- Pastry display (8\%)

- Tables in the atrium area $(7.1 \%)$

- Tables near entrance $(6.2 \%)$

- Tables in the corner area(5.3\%)

- Decoration of vintage photographs (3.5\%)

- Other $(0.9 \%)$

Calculating from the result, $54.5 \%$ of the respondents choose the elements in the exterior which becomes a transition between Braga Street and the building of Braga Permai, consisting only three out of nine elements shown on the photographs. The first is the restaurant signage which focuses on the typography, showing the name of the restaurant, the second is an umbrella canopy which represents the conserved design element from the past, and the third is the gate which captures an overall area of the outdoor dining.

The rest of the photographs show more specific spots in the interior, but the most significant indoor space is pointed at the tables near pastry etalage (11.5\%). The following spot chosen is pastry display (8\%). Considering that pastry display is shown in both photographs, there is a possibility that the object has become the most remarkable interior element of Braga Permai compares to other elements.

The last part of the questionnaires functions as an affirmation. After being shown the image of an umbrella-canopy as the restaurant's logo, $83.3 \%$ of the respondents agree that umbrella-canopy is iconic for Braga Permai. Through the analysis of the questionnaires result, it is found that the agreeing respondents does not always mention umbrella-canopy as a remarkable element in the previous question. Nevertheless, most of them mention that the outdoor area of the restaurant is remarkable. In this case, the consistency of the respondents is measured not by directly mentioning a specific element but by the context of where the specific element is located, which is classified as interior and exterior.

\section{Conclusion and recommendation}

Based on the results, it is concluded that people today still perceive umbrella-canopy as an icon of Braga Permai. Although not every visitor understands the history of the restaurant $[19,20,21]$, but the where and how the umbrella-canopies are located have made them iconic.
Summarized from the discussions, people have a tendency to consider an element memorable if it is placed in a large space. In the context of a building, an element placed in the outdoor area is generally more remarkable [16]. Observing from the object, umbrella-canopies are placed in the outdoor area of Braga Permai, more specifically next to the pedestrian. Not only the figures are easily seen, their contrast red color also makes people who pass by the street by walk or by any of transportation vehicle can easily spot the top of the umbrella-canopies [22, 23].

The only element that puts umbrella-canopy in a lesser remarkable value is the signage of the restaurant's name which is also located near the pedestrian. However, the value of this element is formed not only by its physical appearance, but also by the meaning of its typography. People might easily memorize the image of the signage based on its design characters or because of what is written by words on the typography. Without the name of Braga Permai gigantically displayed on the sign board, the value of this element is biased. Nonetheless, referring to semiotic theory by Peirce $[8,9]$, it is suggested that this signage board serves more indexical rather than iconic for the restaurant.

A surprising result is shown by a small gap in the agreeance of the respondents regarding the iconic value of umbrella-canopy. Some respondents who exclude any element in the outdoor area as remarkable can also view the umbrella-canopy iconic after being shown the visual graphic on the menu books and website, which illustrates an image of two people dining under a red umbrella-canopy. This means, even though architectural design elements still hold the main factors, visual graphic also play supports in directing people's perception towards icon. In this case, visual graphic helps bridging the missing information about the history of Braga Permai to people from the present time [24,25].

Regarding the contribution to the restaurant and to the sustainability of cultural heritage in Bandung, the recent logo used by the restaurant is already in accordance to what visitors perceive an as icon, and should be effective for any further marketing programs or even merchandising [23]. Since visitors already capture the iconic value of the umbrella-canopy, this image is recommended conserved when future development or building renovation occurs. The 
conservation does not necessarily have to be in an accurate precision, but factors such as: located in the exterior space, visible from the street, having a contrast color, and functioning to shade several outdoor dining, should be maintained as they have come out as key factors that prompt visitors to perceive umbrella-canopy as an icon of Braga Permai.

\section{REFERENCES}

[1] Ardiyanto, A., Djunaedi, A., Ikaputra, S., Djadmika, A., 2014, The Concept of Modern Dutch Colonial Architecture to Development of Javanese Architecture, Journal of Architecture and Built Environment, vol. 41, No. 1, 37-42.

[2] Vitra, Kristiani, 2015, The heritage of the people : cultural mapping of an art community on Braga Street, Bandung City, West Java, Indonesia.

[3] Hermawan, Iwan, 2012, Menjadikan Tinggalan Kolonial di Kota Bandung sebagai Obyek Wisata. Jurnal Penelitian dan Pengembangan Kepariwisataan, Vol. 7(1), 2012, 85-97

[4] C.N. van der Heiden, 1990, Town planning in the Dutch Indies, Planning Perspectives, 5:1, 63-84

[5] Widyaevan, D.A., 2015, The Change of Public Perception towards Alun-alun Bandung as a City Center,

[6] Kunto, Haryoto. Wajah Bandung Tempo Doeloe. Bandung : PT. Granesia, 1984, pg.319-320

[7]https://www.tripadvisor.co.id/Restaurant_Review-g297704-d3 984291-Reviews-Braga_Permai_Resto-Bandung_West_Java _Java.html accessed june 5, 2017, 14:33

[8] Buchler, Justus, Philosophical Writings of Peirce. New York : Dover Publishing Inc. : 1955

[9] Yakin, H.S.M, and Totu, A., 2014, The Semiotic Perspectives of Peirce and Saussure : A Brief Comparative Study. Procedia - Social and Behavioral Sciences 155 (2014) 4-8

[10] Ghafari, A., Falamaki, M.M., and Habib, F., 2015, Evaluation the Theories of Semiotics Approach in the REading of Architecture and Urbanism, International Journal of Review in Life Sciences, 5(4), 642-649.

[11] Berger, Arthur A., Tanda-tanda dalam Kebudayaan Kontemporer. Yogyakarta : Penerbit Tiara Wacana, 2015

[12] Grayson, Kent and Martinec, Radan, 2004, Consumer Perception of Iconicity and Indexicality and Their Influence on Assessments of Authentic Market Offerings. Journal of Consumer Research, Vol. 31, No.2, pp. 296 - 312
[13] Peirce, Charles Sanders, 1998, Collected Papers of Charles Sanders Peirce, ed. Charles Hartshorne, Paul Weiss, and Arthur Blank, 8 vols., Bristol : Thoemmes, pg. 448, CP 2.435

[14] Karnaya, I., Kusumawardhani, R.A., Handayani, N.D., and Atmodiwirjo, P.,, 2014, Visual and Sound Intervention in Art and Space : The Making of Spatial, Proceeding Arte-Polis 5th International Conference, Vol. 1, 8-17.

[15] Kotsi, F., Balakrishnan, M.S., Michael, I., and Ramsoy, T.Z., 2016. Place Branding : Aligning Multiple stakeholder perception of Visual and Auditory Communication Elements. Journal of Destination Marketing \& Management (article in press)

[16] Walter, U. and Edvardsson, B., 2012, The physical environment as a driver of customers' service experiences at restaurants. International Journal of Quality and Service Sciences, Vol. 4 Issue 2, pp.104-119.

[17] Kimchi, R., Yeshurun, Y., Spehar, B., and Pirkner, Y., 2015, Perceptual Organization, Visual Attention, and Objecthood. Vision Research (article in press)

[18] Rahardjo, S., and Widyaevan, D.A., 2015, Decoding Ambiguous Spaces in the School of Creative Industries Building, Telkom University (TCIS Building), Proceeding 3rd International Conference on Creative Industries, Vol. 1, 235-242

[19] Wilson, E.J., Bengstsson, A., and Curran, C., 2014, Brand meaning gaps and dynamics : theory, research, and practice. Qualitative Market Research : An International Journal, Vol. 17 (2), 128-150, DOI : 10.1108/QMR-12-2013-0094

[20] Hammerl, M., Dorner, F., Foscht T., and Brandstatter, M., 2016, Attribution of symbolic brand meaning : the internplay of consumers, brands and reference groups. Journal of Consumer Marketing, Vol. 33 (1), 32-40.DOI : 1108/JCM-12-2014-1243

[21] Molleda, Juan-Carlos, 2010, Authenticity and the construct's dimensions in public relations and communication research. Journal of Communication Management, Vol., 14 Issue 3, pp. 223-236.

[22] Aslam, Mubeen M., 2006, Are You Selling the Right Colour? A Cross-cultural Review of Colour as a Marketing Cue, Journal of Marketing Communications, 12:1, 15-30, DOI: $10.1080 / 13527260500247827$

[23] Kleinova, K., Paluchova, J., Bercik, J., and Horska, E., 2015, Visual MErchandising and Its Marketing Components in the Chosen Restaurant in Slovakia. Procedia Economics and Finance 34, 3-10. 
[24] Müller, B., Kocher, B., Crettaz, A., 2013, The effects of visual rejuvenation through brand logos. Journal of Business Research $66,82-88$

[25] Magnini, V.P. and Kim, S., 2015, The Influences of Restaurant Menu Font Style, Background Color, and Physical Weight on Consumers's Perception. International Journal of Hospitality Management 53 (2016) 42-48. 